\title{
Concentration and characterization of microalgae proteins from Chlorella pyrenoidosa
}

\author{
Ashish G. Waghmare', Manoj K. Salve', Jean Guy LeBlanc ${ }^{2}$ and Shalini S. Arya ${ }^{\text {** }}$
}

\begin{abstract}
Background: Many methods are available for the concentration of proteins; however, most are not easily scalable due to costs, the need of specialized instruments and skilled workers or are very time-consuming. Three-phase partitioning (TPP) is a separation technique that has gained a lot of interest due to its rapid, simple and scalable use for concentration, isolation and decontamination of proteins from crude samples with high recovery yields. In the present work, the effect of various parameters of TPP was evaluated to optimize the concentration of proteins from Chlorella pyrenoidosa (CP), is green algae that increasingly being used as food supplements because of its positive impacts on human health.

Results: Chlorella pyrenoidosa was cultivated in a closed system under controlled conditions. After reaching maximum growth, the microalgae was harvested, dried and powdered. Afterwards, TPP of CP cell lysate was done to concentrate protein content. To maximize protein concentration, various parameters were optimized such as solvent ( $t$-butanol), ammonium sulphate concentration (40\% w/v), solid load $(0.75 \mathrm{~g} / 20 \mathrm{~mL}), \mathrm{pH}(6)$, incubation time (20 min), slurry to butanol ratio (1:1.5) and enzymatic treatment (combination of Stargen ${ }^{\mathrm{TM}}$ and Carezyme ${ }^{\mathrm{TM}}$ ). Also, total starch, cellulose and carbohydrate content before and after the enzymatic treatment were determined to comprehend the impact of enzymatic treatment on protein concentration. Using these optimized parameters, $78.1 \% \mathrm{w} / \mathrm{w}$ protein concentration was obtained in middle protein concentrate phase. This protein concentrate was characterizedfor proximate composition, colour analysis, water holding capacity, oil-holding capacity, foaming capacity, foam stability, amino acid composition, protein quality and thermal properties.

Conclusion: Various process parameters of TPP influence the protein concentration of middle protein concentrate phase. Enzymatically treated biomass also enhanced protein concentration in middle protein concentrate phase. Characterization of protein concentrate revealed the presence high-quality protein. Therefore, it is possible to implement TPP at an industrial scale for protein concentration.
\end{abstract}

Keywords: Microalgae, Three-phase partitioning, Protein concentrate, Enzymatic treatment, Protein quality

\section{Background}

Microalgae proteins have a great potential to be an alternative protein source since they contain all essential amino acids (Becker 2007; Barbarino and Lourenço 2005; Lourenco et al. 2004; Safi et al. 2014a, b). Microalgae have

\footnotetext{
*Correspondence: shalu.ghodke@gmail.com

${ }^{1}$ Food Engineering and Technology Department, Institute of Chemical Technology, Nathalal Parekh Marg Matunga, Mumbai 400019 ,

Maharashtra, India

Full list of author information is available at the end of the article
}

created immense interest due to their unconventional growth requirements such as being able to grow in salt water in the presence of $\mathrm{CO}_{2}$ and sunlight on unfertile land. This makes microalgae a potentially sustainable source of feedstock for fuel, food, chemical, textile, polymer and even the pharmaceutical industry (Viegas et al. 2015). Microalgae contain lipids, protein and carbohydrate as their main components and their protein concentrates can be used in the food, feed and bulk chemical industry (Chacon-Lee and Gonzalez-Marino 2010).

\section{Springer Open}


Chlorella pyrenoidosa (CP) is a species of the freshwater green algae that is widely used as food supplements (Garcia et al. 2012; Wang and Zhang 2012). Each year, the United States, Japan, China, Taiwan and Indonesia produce over 2500 tons of dried Chlorella (Bishop and Zubeck 2012) because it is not only considered a good source of nutrients but also a functional food due to its positive health effects (Gao 1998; Richmond 1990). Various clinical and animal studies have shown that $\mathrm{CP}$ is a safe source of protein for consumption and dietary supplementation with Chlorella may reduce high blood pressure, lower serum cholesterol and glucose levels, accelerate wound healing, and enhance immune functions (Viegas et al. 2015; Cherng and Shih 2005; Halperin et al. 2003; Lee et al. 1967; Merchant and Andre 2001; Merchant et al. 2002; Mizoguchi et al. 2008; Lisboa et al. 2014). Microalgae proteins also have high technofunctional potential such as being usable as an emulsifier (Ursu et al. 2014). Since proteins from Chlorella can act as an animal protein replacement, its use can have a positive impact on the environment (Jones 2016).

Many methods have been used for fractionation/concentration of proteins from microalgae such as ultrafiltration, precipitation, chromatography, dialysis and centrifugation. Even though these methods are effective, they are not easily scalable due to the costs of the process, requirement of a specialized instrument, time-consuming and the need of skilled operators. The drawbacks of ultrafiltration include the susceptibility of rapid membrane clogging, prolonged processing time and the use of expensive membrane filters (Walsh 2007). Precipitation is an industrially suitable method for protein concentration and is performed by salting out, isoelectric focusing and solvent precipitation. However, each of these methods has their limitation such as the low recovery during salting out and irreversible denaturation of proteins after isoelectric focusing and solvent precipitation (Ustunol 2015). Chromatography, dialysis and centrifugation are preferable methods for final-stage purification of proteins but are very much time-consuming (Bio-Sciences 2010). Three-phase partitioning (TPP) is a separation technique useful for initial purification of proteins with high recovery yields. It has gained a lot of interest due to its rapid, simple and scalable use for concentration, isolation and decontamination of proteins from crude samples (Harde and Singhal 2012). TPP can efficiently fractionate nonpolar components in solvent phase (upper phase), polar components in aqueous (lower phase) and proteins in the middle phase. This technique uses a combination of ammonium sulphate and $t$-butanol to precipitate proteins from crude extracts. Precipitated protein binds to $t$-butanol, thereby increasing their buoyancy and causing the precipitates to float above the denser aqueous salt phase. Optimum $\mathrm{pH}$, temperature, ammonium sulphate and $t$-butanol concentrations can selectively precipitate proteins at the interface of the organic and aqueous phases. Kosmotropic, salting out, co-solvent precipitation, isoionic precipitation, osmotic electrostatic forces, conformation tightening and protein hydration shifts all contribute to protein precipitation at this interface (Vetal and Rathod 2014). It has been reported that TPP can even enhance enzyme activity compared to conventional methods (Garg and Thorat 2014; Ketnawa et al. 2014; Ozer et al. 2010; Sen et al. 2011). Furthermore, the protein recovery yield is almost perfect reaching values near $100 \%$ of the total protein present (Phongthai and Rawdkuen 2015).

In the present work, the effect of various parameters of the TPP method was evaluated to optimize the concentration of proteins from CP. The effect of an enzymatic treatment on protein concentration efficiency was evaluated by quantifying initial and final starch, cellulose and total carbohydrate concentrations. Also, the protein concentrate obtained using optimized conditions was characterized to understand the influence of the TPP method.

\section{Methods}

All chemicals, salts, solvents and reagents used in this study were of analytical grade and were purchased from SD Fine, Mumbai, India. Stargen ${ }^{\mathrm{TM}} 002$ was gifted from Genencor International, Danisco US and Carezyme ${ }^{\mathrm{TM}}$ was procured from Sigma-Aldrich, USA. Corn oil was gifted by Kamani oils, Mumbai, India.

\section{Culture growth conditions and harvesting}

The species Chlorella pyrenoidosa strain NCIM 2738 is a freshwater green alga from the genus Chlorella. This strain was obtained from National Centre for Industrial Microorganisms (NCIM), Pune, India. Batch size of $40 \mathrm{~L}$ (20 flasks) was cultivated in 3-L glass conical flasks containing $2 \mathrm{~L}$ modified Chlorella medium in each flask and sterilized in an autoclave at $120{ }^{\circ} \mathrm{C}, 15$ bar pressure for 20 min. Modified chlorella medium, adjusted to $\mathrm{pH}$ 7.5, consisted of following components (g/l): $\mathrm{KNO}_{3}(4)$, $\mathrm{NaNO}_{3}(0.1), \quad \mathrm{MgSO}_{4} \cdot 7 \mathrm{H}_{2} \mathrm{O}$ (0.1), $\mathrm{CaCl}_{2} \cdot \mathrm{H}_{2} \mathrm{O}$ (0.05), $\mathrm{H}_{3} \mathrm{BO}_{3}$ (0.00286), $\mathrm{MnCl}_{2} \cdot 4 \mathrm{H}_{2} \mathrm{O}(0.00181), \mathrm{ZnSO}_{4} \cdot 7 \mathrm{H}_{2} \mathrm{O}$ (0.00022), $\quad \mathrm{NaMoO}_{4} \cdot 2 \mathrm{H}_{2} \mathrm{O} \quad(0.0004), \quad \mathrm{CuSO}_{4} \cdot 5 \mathrm{H}_{2} \mathrm{O}$ (0.00008), $\quad \mathrm{FeSO}_{4} \cdot 7 \mathrm{H}_{2} \mathrm{O}$ (0.00557), and $\mathrm{Na}_{2}$ EDTA (0.00745). The flasks were maintained in a plant growth chamber where the illumination (800-1000 lux) was provided by cool white fluorescent lamps (Philips) and light intensity was measured with an LUX meter. The temperature was maintained at $25 \pm 2{ }^{\circ} \mathrm{C}$ and flasks were agitated twice daily for $2 \mathrm{~min}$ at 60 revolutions per min. Ten-day-old cultures were inoculated in the media-containing flasks and incubated during 45 days. The biomass 
was harvested by sedimentation and further centrifuged (Backman J2-MC, USA) at $5000 \times g$ for $10 \mathrm{~min}$ to collect the thick algal slurry. The algae slurry was washed with distilled water to remove salts. This slurry was dried in an oven at $50{ }^{\circ} \mathrm{C}$ for $24 \mathrm{~h}$. Dried biomass was ground and passed through 36-mesh-size sieve to obtain uniform particle size then stored at $-20{ }^{\circ} \mathrm{C}$ in an air-tight seal container until used. Afterwards, cell disruption of dried biomass was performed using ultrasonication (Branson Ultrasonifier 450, USA) and disruption was confirmed by microscopic (Motic BA310, with Moticam 480, China) observation at $40 \times$.

\section{Three-phase partitioning}

TPP of cell lysed CP biomass was carried out to concentrate its proteins. In $100 \mathrm{~mL}$ glass beakers, $20 \mathrm{~mL}$ cell lysed biomass was mixed with $8 \mathrm{~g}$ of ammonium sulphate followed by addition of $20 \mathrm{~mL} t$-butanol. This mixture was stirred for $20 \mathrm{~min}$ at $28 \pm 2{ }^{\circ} \mathrm{C}$. Immediately, three distinct phases were separated carefully using Pasteur pipette. Initially, the upper organic phase was pipetted then lower aqueous phase was pipetted by piercing middle phase. The middle phase, containing the concentrated proteins (see "Background" section), was used for further study. Salt was removed from protein concentrate using Hi-media dialysis membrane- 50 for $12 \mathrm{~h}$ in $1 \mathrm{~L}$ distilled water (fresh distilled water was replaced after 6 h). Dialysed protein concentrate was precipitated by adjusting the $\mathrm{pH}$ to 5.0 followed by centrifugation at $8000 \times g$ for $10 \mathrm{~min}$ to remove water. This protein concentrate was dried at $50{ }^{\circ} \mathrm{C}$ for $12 \mathrm{~h}$ and used for analysis. Effect of various process parameters was evaluated such as solvent, ammonium sulphate, solid load, $\mathrm{pH}$, incubation time, slurry to butanol ratio and enzymatic treatment. The protein concentration of middle phase proteins was represented as a concentrate in $\% \mathrm{w} / \mathrm{w}$.

\section{Protein quantification}

Protein concentration in middle phase was determined by the modified Kjeldahl method (Persson et al. 2008). This method mainly involved digestion, distillation and titration (Kel-Plus, Elite Ex 8L, Pelican equipments, India). For microalgae and cyanobacteria undergoing rapid growth, the recommended Kjeldahl nitrogen-toprotein conversion factor used was 5.95 instead of 6.25 (Lopez et al. 2010). In the case of enzymatically treated biomass, the amount of enzyme used was subtracted from total protein concentration found, to eliminate the contribution of enzymes in protein quantification. In every run, two digestion tubes were kept as blanks. All samples were analysed in triplicate and mean with standard deviation was reported.

\section{Effect of enzymatic treatment on protein concentration Enzymatic treatment}

Effect of enzymatic treatment on protein concentration was studied using Stargen ${ }^{\mathrm{TM}} 002$ (570 GAU/g from Genencor International) and Carezyme ${ }^{\mathrm{TM}}(1000 \mathrm{U} / \mathrm{g}$ from Sigma-Aldrich). Cell disrupted microalgae slurry was treated separately with each individual enzyme and also, both enzymes were used together to evaluate the combined effect. Simultaneously, non-enzymatic treated cell lysates were used as controls. The condition during Stargen ${ }^{\mathrm{TM}} 002$ treatment was $\mathrm{pH}$ (4.5), temperature $\left(50{ }^{\circ} \mathrm{C}\right)$ and enzyme loading $(10 \mu \mathrm{g}$ for $0.75 \mathrm{~g}$ of cell lysate in $20 \mathrm{~mL}$ distilled water) for $1 \mathrm{~h}$ with gentle stirring $(300 \mathrm{rpm})$ using a magnetic stirrer. For, Carezyme ${ }^{\mathrm{TM}}$ treatment conditions were $\mathrm{pH}(5)$, temperature $\left(37^{\circ} \mathrm{C}\right)$ and enzyme loading (10 $\mu \mathrm{g}$ for $0.75 \mathrm{~g}$ of cell lysate in $20 \mathrm{~mL}$ distilled water) for $1 \mathrm{~h}$ with gentle stirring (300 rpm) using a magnetic stirrer. The combined effect of Stargen $^{\mathrm{TM}} 002$ and Carezyme ${ }^{\mathrm{TM}}$ was studied by first treating the cell lysate with Stargen ${ }^{\mathrm{TM}} 002$ followed by Carezyme $^{\mathrm{TM}}$ treatment both in the conditions described above for each individual enzyme. Effect of enzymatic treatment was assessed by determining protein concentration, starch, cellulose and total carbohydrate of TPP middle phase protein concentrate powder as described below.

\section{Total starch quantification}

Starch content was determined using a modified method of Takeshita et al. (2014). Briefly, $0.5 \mathrm{~g}$ of each sample was homogenized in $80 \%$ ethanol at $50{ }^{\circ} \mathrm{C}$ to remove sugars. The residue was separated by centrifugation at $5000 \times g$ for $10 \mathrm{~min}$ then washed repeatedly with $80 \%$ ethanol at $50{ }^{\circ} \mathrm{C}$ until the washings did not give a colour with anthrone reagent and removed all pigments. This residue was completely dried over a water bath then $2.5 \mathrm{~mL}$ of water and $2.5 \mathrm{~mL}$ of $60 \%$ perchloric acid were added. These tubes were kept at $0{ }^{\circ} \mathrm{C}$ for $20 \mathrm{~min}$ for starch extraction. The supernatant was separated by centrifugation at $5000 \times g$ for $10 \mathrm{~min}$ and stored. The extraction was repeated using fresh $60 \%$ perchloric acid and the supernatant was separated by centrifugation at $5000 \times g$ for $10 \mathrm{~min}$. From the supernatant, $1 \mathrm{~mL}$ of extract was pipetted and $4 \mathrm{~mL}$ of anthrone reagent was added to each tube. Afterwards, the test tubes were heated in a boiling water bath for $10 \mathrm{~min}$ then cooled to room temperature, and the absorbance at $630 \mathrm{~nm}$ was measured using a spectrophotometer. Glucose was used as a standard for calibration graph to determine glucose concentration in samples. Starch content was calculated by multiplying the value by a factor 0.9 . 


\section{Cellulose quantification}

Cellulose was quantified as described by Thayumanavan and Sadasivam (1984). Acetic/nitric reagent (3 mL of a solution consisting of 10 volumes of $80 \%$ acetic acid and 1 volume of concentrated nitric acid) was added to $0.5 \mathrm{~g}$ of the sample in a test tube and mixed using a vortex mixer. The tubes were then placed in a water bath at $100{ }^{\circ} \mathrm{C}$ for $30 \mathrm{~min}$, cooled and centrifuged at $5000 \times \mathrm{g}$ for $15 \mathrm{~min}$. The supernatant was discarded and cellulosecontaining residue was washed with distilled water. To this residue, $10 \mathrm{~mL}$ of $67 \%$ sulphuric acid was added and allowed to stand for $1 \mathrm{~h}$. Further, 1 in 100 dilution was made and $1 \mathrm{~mL}$ of this diluted solution combined with $10 \mathrm{~mL}$ of anthrone reagent $(200 \mathrm{mg}$ anthrone in $100 \mathrm{~mL}$ chilled concentrated sulphuric acid) was added and mixed well. The tubes were heated in a boiling water bath for $10 \mathrm{~min}$. Further, tubes were cooled and the absorbance at $630 \mathrm{~nm}$ was measured. Blank was prepared with anthrone reagent and distilled water and the calibration curve was prepared using cellulose in the range of $40-200 \mu \mathrm{g}$.

\section{Total carbohydrate quantification}

A sample $(100 \mathrm{mg})$ was taken in a test tube and $5 \mathrm{~mL}$ of $2.5 \mathrm{~N} \mathrm{HCl}$ was added and kept in boiling water bath for $3 \mathrm{~h}$ for hydrolysis. This solution was allowed to cool and was neutralized using sodium carbonate until effervescence ceases. Volume was adjusted to $100 \mathrm{~mL}$ with distilled water and centrifuged at $8000 \times g$ for $20 \mathrm{~min}$. The supernatant was collected and $1 \mathrm{~mL}$ aliquot was taken for analysis to which $4 \mathrm{~mL}$ of anthrone reagent was added followed by heating for $10 \mathrm{~min}$ in boiling water bath. After cooling to room temperature, absorbance was measured at $630 \mathrm{~nm}$. Glucose was used as a standard for the preparation of calibration graph (Thayumanavan and Sadasivam 1984) and distilled water was used as blank in place of sample.

\section{Characterization of protein concentrate Proximate composition of dried biomass and protein concentrate}

Samples were analysed for moisture and total ash contents following standard AOAC (2001) method. Total protein content was determined using the micro-Kjeldahl procedure with a nitrogen-to-protein conversion factor of 5.95 (Lopez et al. 2010). Fat content was determined by the Soxhlet method (using Instant Soxhlet apparatus-Socs Plus, Pelican Equipments, Chennai, India) using petroleum ether (B. P. $60-80{ }^{\circ} \mathrm{C}$ ) as the solvent. Carbohydrate was estimated by difference [Percentage carbohydrate content $=100-(\%$ moisture $+\%$ ash + protein $+\%$ fat)] and also using the method with anthrone as described above.

\section{Color analysis}

Color of the dried biomass and protein concentrate were measured using Hunter Lab colorimeter model DP-9000 D25A (Hunter Associates Laboratory, Reston, VA, USA) in terms of Hunter L (lightness, ranging from 0 to 100 indicating black to white), a ( $+\mathrm{a}$, redness and $-\mathrm{a}$, greenness) and $b(+b$, yellowness and $-b$, blueness). The determination of color was done on six different samples. Standardisation of the instrument was done using a black and white standard plates.

\section{Water-holding capacity (WHC) and oil-holding capacity (OHC)}

To determine WHC, 1 g protein concentrate was dispersed in $10 \mathrm{~mL}$ of distilled water and placed in centrifuge tubes. The dispersions were stirred for $5 \mathrm{~min}$, held for $30 \mathrm{~min}$, followed by centrifugation at $3000 \times g$ for $25 \mathrm{~min}$. The supernatant was eliminated, the excess of water was removed by draining for $25 \mathrm{~min}$ at $50{ }^{\circ} \mathrm{C}$ and the sample was reweighed. For $\mathrm{OHC}, 0.5 \mathrm{~g}$ of sample was mixed with $6 \mathrm{~mL}$ of corn oil and allowed to soak for $30 \mathrm{~min}$. Then, tubes were centrifuged at $3000 \times g$ for $25 \mathrm{~min}$. The separated oil was then removed with a pipette and the tubes were inverted for $25 \mathrm{~min}$ to drain the oil prior to reweighing. The $\mathrm{WHC}$ and $\mathrm{OHC}$ were expressed as grams of water or oil bound per $100 \mathrm{~g}$ of the sample on dry weight basis (Ghribi et al. 2015).

\section{Foaming capacity (FC) and foaming stability (FS)}

Samples were dispersed in $50 \mathrm{~mL}$ distilled water at a concentration of $3 \%(\mathrm{w} / \mathrm{v})$ and homogenized at $8000 \times g$ for $3 \mathrm{~min}$. The blend was immediately transferred into a graduated cylinder. The volume was recorded before and after whipping. FC was expressed as the volume (\%) increase due to whipping.

$$
\begin{aligned}
\text { Foaming capacity }(\%)= & \frac{(\text { Volume after }- \text { Volume prior })}{\text { Volume prior }} \\
& \times 100 .
\end{aligned}
$$

For the determination of FS, foam volume changes in the graduated cylinder were recorded after $180 \mathrm{~min}$ of storage and expressed in percentage (Cano-Medina et al. 2011).

\section{Amino acid composition and protein quality}

Amino acid composition was determined using highpressure liquid chromatography (HPLC). The sample of protein concentrate was dissolved in $6 \mathrm{~mL}$ of $6 \mathrm{~N}$ $\mathrm{HCl}$ and was subjected to hydrolysis in boiling water bath for a period of $24 \mathrm{~h}$. The tubes were vortex mixed after every $1 \mathrm{~h}$ for proper hydrolysis. After $24 \mathrm{~h}$ of hydrolysis, the tubes were centrifuged at $3500 \times g$ for 
15 min. The supernatant was filtered and was neutralized with $1 \mathrm{~N} \mathrm{NaOH}$. Then, the filtered solution was diluted to 1:100 with HPLC grade water and was used for estimation of protein amino acids in HPLC (Huesgen 1999; Sonawane et al. 2015). Protein quality was evaluated by the essential amino acid index (EAAI), which is based on the content of all essential amino acids compared to a reference protein and human requirements as mentioned in $\mathrm{FAO} / \mathrm{WHO} /$ UNU standard (2007). The EAAI is a rapid method to evaluate and optimize the amino acid content of food formulations (Smith and Nielsen 2010). CP protein concentrate by TPP was comparatively evaluated with literature data on best protein sources such as soy protein and casein. However, EAAI does not include any estimate of protein digestibility, which could be affected by processing method.

Essential Amino Acid Index (EAAI) was calculated using the following equation:

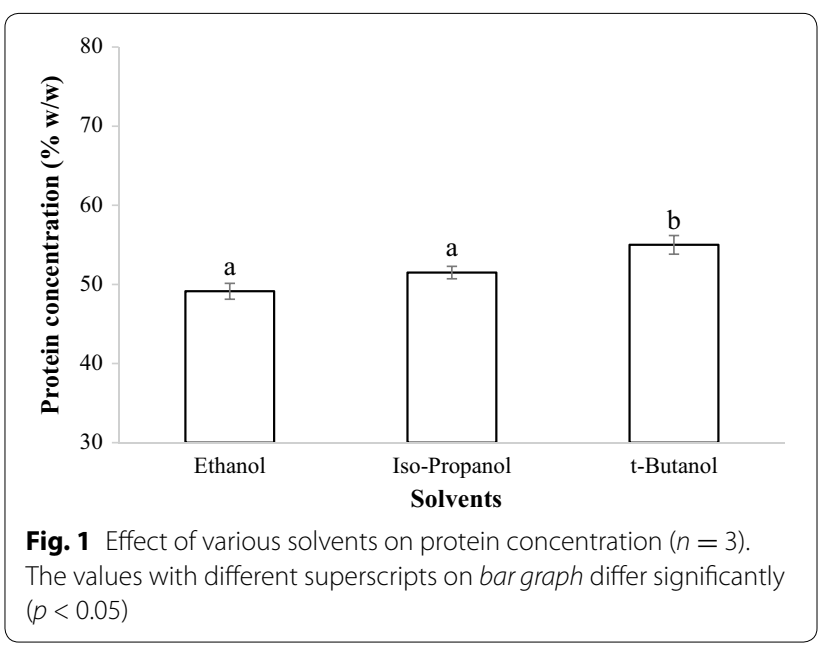

was found that $t$-butanol was the best solvent for TPP of cell lysate to obtain the maximum protein concentration.

$$
=\sqrt[9]{\left(\frac{\mathrm{mg} \text { of lysine in } 1 \mathrm{~g} \text { of the test protein }}{\mathrm{mg} \text { of lysine in } 1 \mathrm{~g} \text { reference protein }}\right) \times(\text { etc. For other 8essential AA })} .
$$

\section{Thermal properties}

To study thermal properties, differential scanning calorimetry (DSC) analysis was done using DSC-60 (Shimadzu Scientific Instruments, Kyoto, Japan) instrument fitted with TA 60 WS detector and computer-aided data analysis. The empty sample and reference pans were taken of equal mass for analysis. $5.00 \pm 0.25 \mathrm{mg}$ of sample was weighed in the DSC pan, sealed hermetically and placed on the sample side. A hermetically sealed identical empty pan was placed on the reference side. Scans were performed between 30 and $200{ }^{\circ} \mathrm{C}$ at a heating rate of $5{ }^{\circ} \mathrm{C} / \mathrm{min}$ with $70 \mathrm{~mL} / \mathrm{min}$ nitrogen gas purging.

\section{Statistical analysis}

The significant difference between mean values was assessed by one-way analysis of variance (ANOVA). Tukey test was carried out using SPSS 16.0 software to determine whether there was any significant difference at the level of $p<0.05$.

\section{Results and discussion TPP of Chlorella pyrenoidosa cell lysate for protein concentration \\ Effect of solvent on protein concentration}

As shown in Fig. 1, the effect of ethanol, isopropanol and $t$-butanol on protein concentration were studied by keeping other parameters constant such as ammonium sulphate $(20 \% \mathrm{w} / \mathrm{v})$, solid load $(1 \mathrm{~g} / 20 \mathrm{~mL}), \mathrm{pH}(7)$, incubation time $(10 \mathrm{~min})$ and slurry to solvent ratio (1:1). It
In the presence of $t$-butanol, $55 \% \mathrm{w} / \mathrm{w}$ of protein concentration was obtained in the middle phase. Solvents act in TPP by increasing the buoyancy of the precipitated protein by binding to it, resulting in a middle phase that locates itself above the denser aqueous salt phase. It was previously shown that $t$-butanol enhanced the buoyancy of precipitated Aloe vera L. protein more efficiently than other alcohols studied (Tana et al. 2015).

\section{Effect of ammonium sulphate on protein concentration}

Various types of salts can be used for TPP but generally, ammonium sulphate is preferred due to its salting out ability. Ammonium sulphate ions are high in the Hofmeister series and easily soluble in water (Ozer et al. 2010; Şen et al. 2011; Dhananjay and Mulimani 2009; Huddleston et al. 1991; Rawdkuen et al. 2012; Roe 2000; Vinoth Kumar et al. 2011). Hence, ammonium sulphate concentration should play a major role in TPP efficiency. At higher salt concentrations, water molecules are attracted by salt ions resulting in stronger protein-protein interactions and the protein molecules coagulate through hydrophobic interactions (Narayan et al. 2008). In the presence of high concentrations of ammonium sulphate, the effective dielectric constant of water greatly increases making $t$-butanol act in a more lipophilic manner increasing hydrophobicity and exclusion from the water. Different concentrations (ranging from 20 to $50 \%$ w/v) of ammonium sulphate were studied for optimization of protein concentration in the middle phase (see 


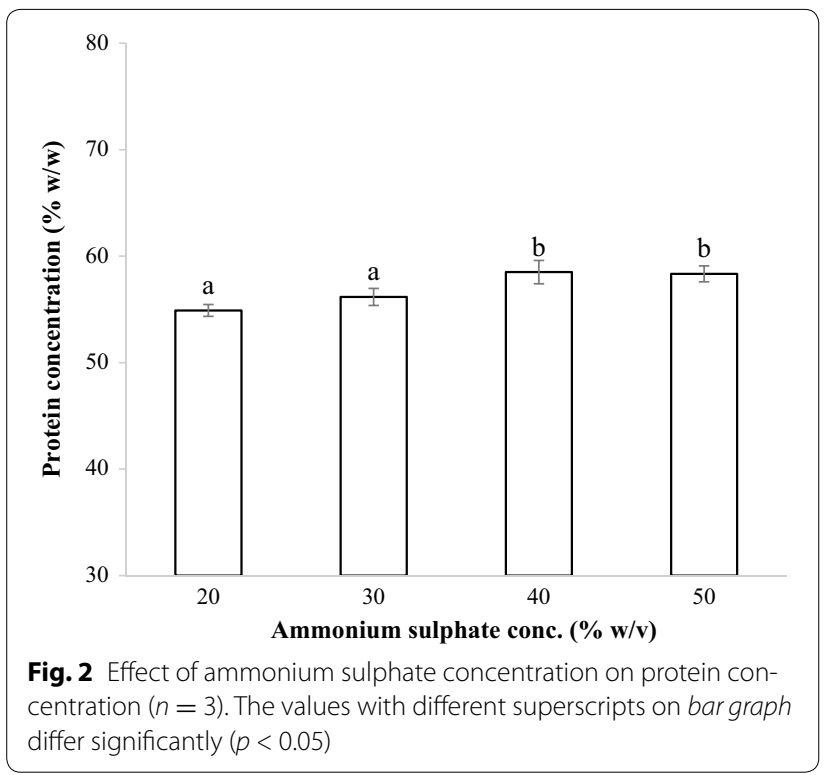

Fig. 2). The optimum protein concentration of $58.5 \% \mathrm{w} / \mathrm{v}$ was obtained in middle phase using $40 \% \mathrm{w} / \mathrm{v}$ ammonium sulphate and keeping the other parameters constant such as solvent ( $t$-butanol), solid load $(1 \mathrm{~g} / 20 \mathrm{~mL}), \mathrm{pH}(7)$, incubation time (10 min) and slurry to butanol ratio (1:1).

\section{Effect of solid load on protein concentration}

The solid load is an important parameter for any kind of extraction process as it can affect the process cost that is dependent on time and solvent requirements (Eskilsson et al. 1999). Optimum protein concentration $(61.8 \% \mathrm{w} / \mathrm{w})$ was obtained at maximum solid load of $0.75 \mathrm{~g} / 20 \mathrm{~mL}$ (see Fig. 3) where solvent ( $t$-butanol), ammonium sulphate concentration (40\% w/v), $\mathrm{pH}(7)$, incubation time (10 $\mathrm{min})$ and slurry to butanol ratio (1:1) were maintained constant.

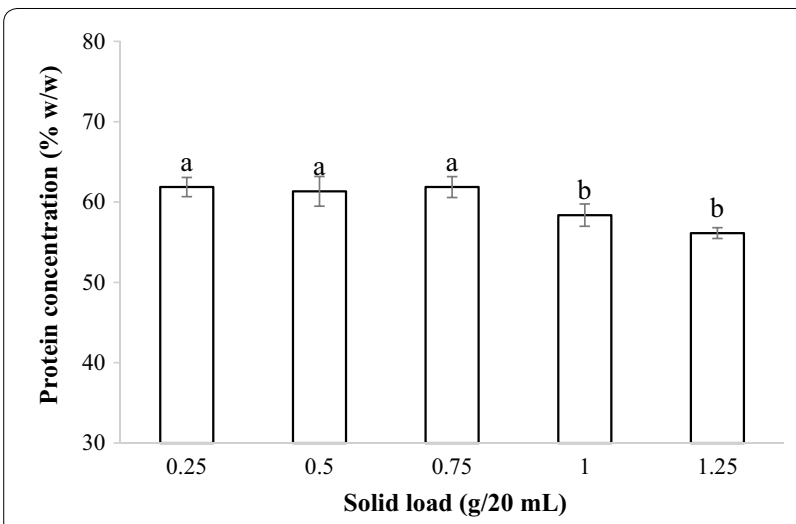

Fig. 3 Effect of solid load on protein concentration $(n=3)$. The values with different superscripts on bar graph differ significantly $(p<0.05)$

\section{Effect of $\mathrm{pH}$ on protein concentration}

$\mathrm{pH}$ significantly influences TPP of protein since it affects the state of ionization of acidic or basic amino acids. Change in $\mathrm{pH}$ facilitates changes in the net charge of protein and also affects the partitioning behaviour of the protein. In the present study, different $\mathrm{pH}$ values (from 5 to 8) were used to study their effect on protein concentration in protein concentrate phase. As shown in Fig. 4, at $\mathrm{pH} 6$ optimum protein concentration of $64.5 \% \mathrm{w} / \mathrm{v}$ was obtained where other experimental parameters such as solvent ( $t$-butanol), ammonium sulphate concentration $(40 \% \mathrm{w} / \mathrm{v})$, solid load $(0.75 \mathrm{~g} / 20 \mathrm{~mL})$, incubation time (10 $\mathrm{min}$ ) and slurry to butanol ratio (1:1) remained constant with all $\mathrm{pH}$ values evaluated. From these results, it can be concluded that in slightly acidic $\mathrm{pH}$ conditions, most of the protein concentrated in middle protein concentrate phase. As $\mathrm{pH}$ increases to slightly alkaline values, protein concentration was decreased, probably due to slightly increased solubility of protein in aqueous phase.

\section{Effect of incubation time on protein concentration}

Preferably minimum time for any process is a prerequisite for any industrial process as a cost-saving measure. Incubation time was varied from 5 to $25 \mathrm{~min}$. Optimum protein concentration $(68.0 \% \mathrm{w} / \mathrm{w})$ was found to be after 20 min of TPP (Fig. 5). During optimization of incubation time, other parameters were kept constant such as solvent ( $t$-butanol), ammonium sulphate concentration $(40 \% \mathrm{w} / \mathrm{v})$, solid load $(0.75 \mathrm{~g} / 20 \mathrm{~mL}), \mathrm{pH}(6)$ and slurry to butanol ratio $(1: 1)$.

\section{Effect of slurry to butanol ratio on protein concentration}

Slurry to $t$-butanol ratio was varied to $1: 0.5,1: 1,1: 1.5$ and 1:2 (see Fig. 6). Optimum protein concentration was found to be $71.3 \% \mathrm{w} / \mathrm{w}$ when slurry to $t$-butanol ratio was set to $1: 1.5$, where all other parameters were kept

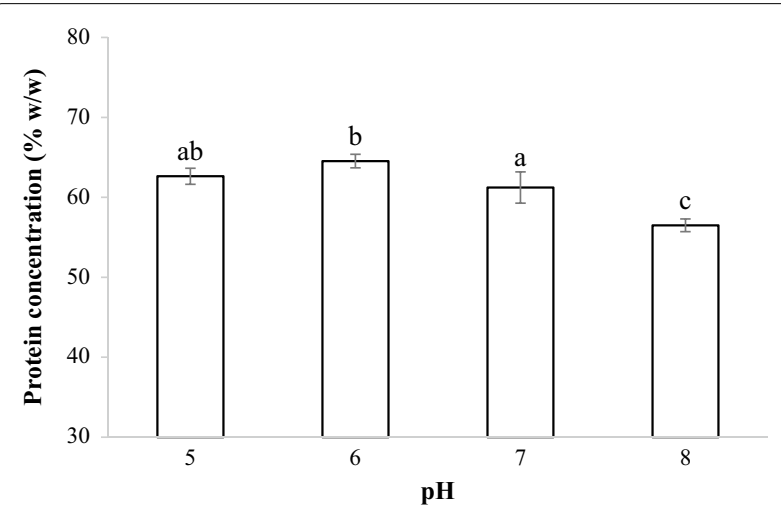

Fig. 4 Effect of $\mathrm{pH}$ on protein concentration $(n=3)$. The values with different superscripts on bar graph differ significantly $(p<0.05)$ 


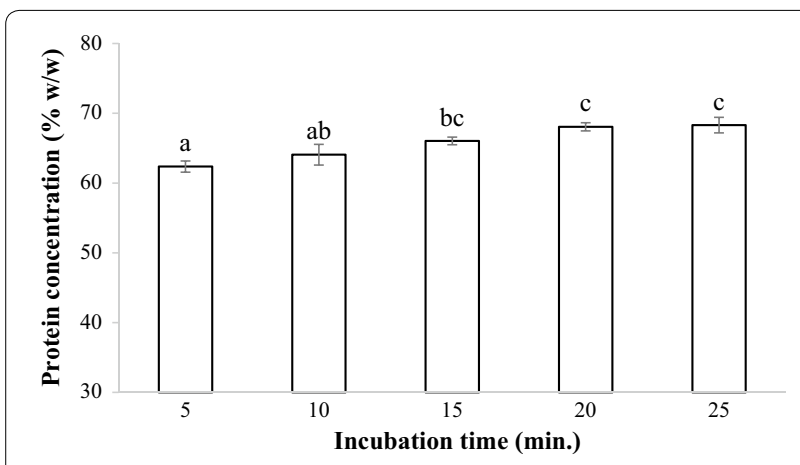

Fig. 5 Effect of incubation time on protein concentration $(n=3)$. The values with different superscripts on bar graph differ significantly $(p<0.05)$

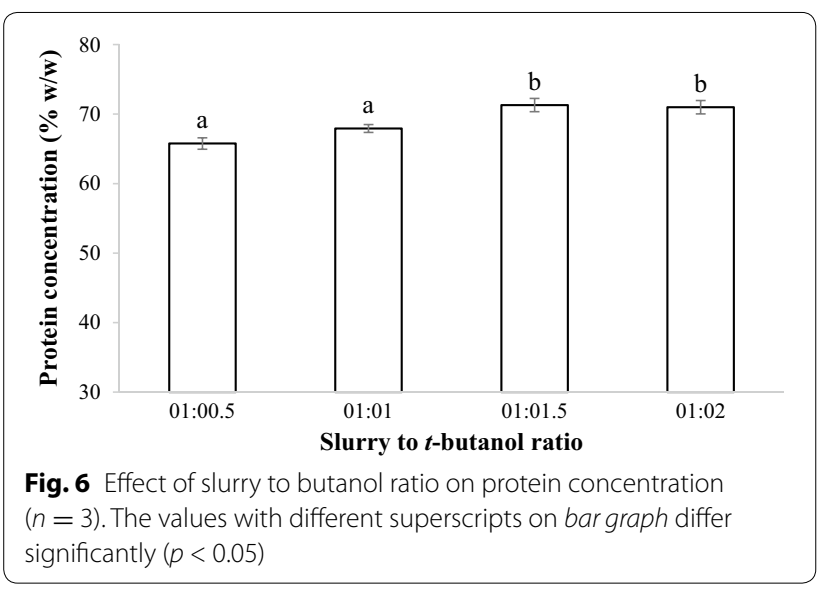

constant such as solvent ( $t$-butanol), ammonium sulphate concentration $(40 \% \mathrm{w} / \mathrm{v})$, solid load $(0.75 \mathrm{~g} / 20 \mathrm{~mL}), \mathrm{pH}$ (6) and incubation time (20 min). As $t$-butanol concentration increases more amount of water fascinates from aqueous phase resultant in better precipitation of protein at the interface. A similar trend was observed previously by Ozer et al. (2010).

\section{Effect of enzymatic treatment on protein concentration}

Previous reports indicate that TPP can be significantly affected by enzymatic treatment (Harde and Singhal 2012). In this study two enzymes were used: (1) Stargen ${ }^{\mathrm{TM}}$ 002 is enzyme mixture that contains Aspergillus kawachi alpha-amylase expressed in Trichoderma reesei and a glucoamylase from Trichoderma reesei that work synergistically to hydrolyse starch to glucose at optimum conditions ( $\mathrm{pH} 4.5$, temperature $50{ }^{\circ} \mathrm{C}$ ) and (2) Carezyme ${ }^{\mathrm{TM}}$ which is cellulase from Aspergillus sp. that hydrolyse cellulose to glucose at optimum conditions ( $\mathrm{pH} 5$, temperature $37^{\circ} \mathrm{C}$ ). Enzymatic treatments were carried out at optimum conditions for the enzymes and processed for TPP. The enzymatic treatment increased protein concentration of middle phase (Fig. 7). This might be due to the fact that even though the cells had been lysed by a physical method of cell disruption, most of the carbohydrates remain bonded with protein matrix that precipitates in the middle phase. This had been proven by quantification of starch, cellulose and total carbohydrate of TPP protein concentrate powder.

Since the enzymatic treatment with Stargen ${ }^{\mathrm{TM}}$ was given before TPP, this decreased the starch content of protein concentrate (Table 1). A similar trend was observed with Carezyme $^{\mathrm{TM}}$ on cellulose content in protein concentrate. It is also possible to observe that a higher content of carbohydrate is found in the control compared to the enzymatically treated samples. This might be due to hydrolysed carbohydrate partitioned into the aqueous phase (polar phase) as explained by Harde and Singhal (2012). Most importantly, it was observed that protein concentration in the concentrate increased after enzymatic treatment. Optimum protein concentration in middle protein concentrate phase of $78.1 \% \mathrm{w} / \mathrm{w}$ was obtained with the combination of both commercial enzyme preparations (Stargen $^{\mathrm{TM}}$ and Carezyme ${ }^{\mathrm{TM}}$ ) as observed when all of the parameters of TPP were maintained constant such as solvent ( $t$-butanol), ammonium sulphate concentration $(40 \% \mathrm{w} / \mathrm{v})$, solid load $(0.75 \mathrm{~g} / 20 \mathrm{~mL}), \mathrm{pH}(6)$, incubation time (20 $\mathrm{min})$ and slurry to butanol ratio (1:1.5).

\section{Characterization of protein concentrate \\ Proximate composition of dried biomass and protein concentrate}

Proximate composition of dried biomass and protein concentrate partitioned by TPP is given in Table 2 . From proximate composition, it can be seen that the obtained protein content was $78.3 \% \mathrm{w} / \mathrm{w}$. Since the resulting protein mixture contained less than $80 \%$ protein, it conforms to the term "protein concentrate" (Ghribi et al. 2015). Fat and carbohydrate content of dried biomass was reduced after TPP whereas proteins were concentrated.

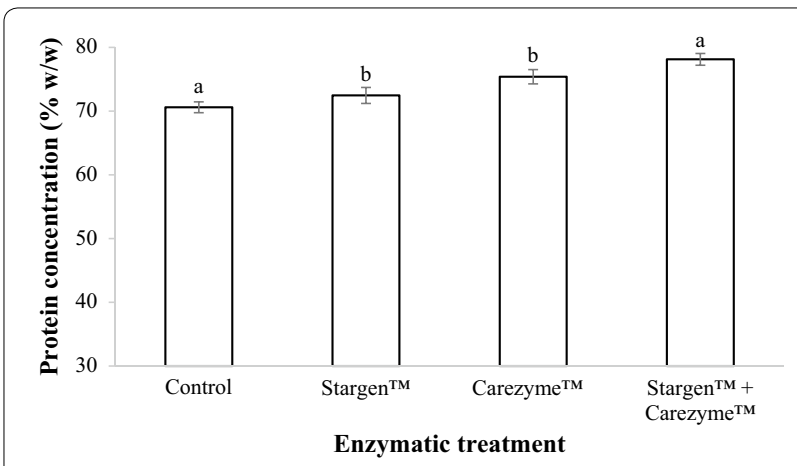

Fig. 7 Effect of enzymatic treatment on protein concentration $(n=3)$. The values with different superscripts on bar graph differ significantly $(p<0.05)$ 
Table 1 Effect of enzymatic treatment on starch, cellulose and total carbohydrate content in protein concentrate $(n=3)$

\begin{tabular}{|c|c|c|c|}
\hline Enzymatic treatment & Starch $(\% \mathrm{w} / \mathrm{w})$ & Cellulose $(\% \mathrm{w} / \mathrm{w})$ & Total carbohydrate (\% w/w) \\
\hline Control (untreated) & $5.30 \pm 0.52$ & $10.16 \pm 1.11$ & $22.43 \pm 0.94$ \\
\hline Stargen $^{\mathrm{TM}}$ & $2.10 \pm 0.25$ & $10.13 \pm 1.00$ & $19.91 \pm 0.80$ \\
\hline Carezyme $^{\mathrm{TM}}$ & $5.03 \pm 0.45$ & $1.40 \pm 0.41$ & $16.06 \pm 1.30$ \\
\hline Stargen $^{\mathrm{TM}}+$ carezyme $^{\mathrm{TM}}$ & $2.20 \pm 0.20$ & $1.23 \pm 0.40$ & $12.80 \pm 0.83$ \\
\hline
\end{tabular}

All the data are expressed as mean \pm SD of three determinations

Table 2 Physiochemical characterization of dried biomass and protein concentrate $(n=3)$

\begin{tabular}{|c|c|c|}
\hline Parameters & $\begin{array}{l}\text { Dried biomass ( } \% \\
w / w)\end{array}$ & $\begin{array}{l}\text { Protein concentrate } \\
(\% \mathrm{w} / \mathrm{w})\end{array}$ \\
\hline Moisture & $6.42 \pm 0.34$ & $4.43 \pm 0.02$ \\
\hline Ash & $4.56 \pm 0.26$ & $4.10 \pm 0.13$ \\
\hline Protein & $45.02 \pm 2.73$ & $78.30 \pm 0.93$ \\
\hline Fat & $22.89 \pm 1.78$ & $4.12 \pm 0.12$ \\
\hline $\begin{array}{l}\text { Carbohydrate (by differ- } \\
\text { ence) }\end{array}$ & 21.11 & 9.05 \\
\hline $\begin{array}{l}\text { Carbohydrate (by } \\
\text { anthrone method) }\end{array}$ & $23.32 \pm 1.05$ & $12.80 \pm 0.83$ \\
\hline $\begin{array}{l}\text { Water-holding capacity } \\
\text { (WHC) }\end{array}$ & ND & $3.09 \pm 0.01$ \\
\hline $\begin{array}{l}\text { Oil-holding capacity } \\
(\mathrm{OHC})\end{array}$ & ND & $2.02 \pm 0.04$ \\
\hline Foaming capacity (FC) & ND & $95.00 \pm 1.14$ \\
\hline Foaming stability (FS) & ND & $97.45 \pm 0.46$ \\
\hline \multicolumn{3}{|l|}{ Thermal characteristic } \\
\hline$T_{0}\left({ }^{\circ} \mathrm{C}\right)$ & ND & $43.29 \pm 1.91$ \\
\hline$T_{d}\left({ }^{\circ} \mathrm{C}\right)$ & ND & $60.10 \pm 2.43$ \\
\hline
\end{tabular}

All the data are expressed as mean \pm SD of three determinations

ND not determined

\section{Colour analysis}

Colour analysis of dried biomass and protein concentrate was comparatively studied since it is an important parameter for improving overall appearance. From Table 3, it was found that $L^{*}$ value changed from 28.3 to 34.8 indicating improved lightness of protein concentrate

Table 3 Colour analysis of dried biomass and protein concentrate $(n=6)$

\begin{tabular}{lcc}
\hline Parameter & Dried biomass & Protein concentrate \\
\hline$L^{*}$ & $28.26 \pm 0.05$ & $34.78 \pm 0.02$ \\
$a^{*}$ & $-0.48 \pm 0.38$ & $0.07 \pm 0.01$ \\
$b^{*}$ & $1.07 \pm 0.03$ & $4.72 \pm 0.03$ \\
\hline
\end{tabular}

All the data are expressed as mean \pm SD of six determinations over dried biomass. Decreased value of $a^{*}$ indicates decreased intensity of green colour in protein concentrate. This might be due to the extraction of green colour pigment in upper $t$-butanol phase. $b^{*}$ values increased from 1.1 to 4.7 showing a decrease in blue colour in protein concentrate.

\section{Water-holding capacity and oil-holding capacity}

Water-holding capacity of protein concentrate can be explained by the presence of polar amino acid and lower amounts of water-soluble protein. WHC of the optimized protein concentrate was $3.1 \mathrm{~g} / \mathrm{mL}$. The presence of nonproteinaceous material in protein concentrate also contributes WHC (Kaur and Singh 2007). The OHC is of great importance from an industrial viewpoint since it reflects the emulsifying capacity, a highly desirable characteristic in products such as mayonnaise. The presence of several non-polar side chains may bind the hydrocarbon chains of fats, thereby resulting in higher absorption of oil (Kaur and Singh 2007). OHC of protein concentrate was $2.1 \mathrm{~g} / \mathrm{mL}$ which is within the range previously published for various protein concentrate of $1.3-4.1 \mathrm{~g} / \mathrm{mL}$. High $\mathrm{OHC}$ is desirable for food formulation (Kaur and Singh 2007).

\section{Foaming capacity $(F C)$ and foaming stability ( FS)}

Foamability is linked with flexible protein molecules that reduce the surface tension which keeps air bubbles in suspension and slows down the rate of coalescence. Globular proteins are relatively stable to surface denaturation which gives low foam. Previously, foaming capacity of winged bean protein concentrate $(36 \%)$, soya isolates $(235 \%)$ and mucuna bean protein concentrate $(58 \%)$ were reported. In this study, the microalgae protein concentrate had an FC of $95 \%$. FS is important since the usefulness of whipping agents depends on their ability to maintain the whip as long as possible. In the case of microalgae protein concentrate, foaming stability was $97 \%$ after $180 \mathrm{~min}$ of storage. This excellent FS suggests that the native proteins that were soluble in the continuous phase (water) were very surface-active in microalgae proteins (Kaur and Singh 2007). 


\section{Amino acid composition and protein quality}

The amino acid composition of $\mathrm{CP}$ protein concentrate partition by TPP was characterized (Table 4). From its amino acid profile, all essential amino acids such as lysine, methionine, threonine, tryptophan, histidine, leucine, isoleucine, valine and phenylalanine were present in the protein concentrate at substantial concentration (Smith and Nielsen 2010). Furthermore, amino acids composition of $\mathrm{CP}$ protein concentrate was comparatively studied and evaluated for the essential amino acid index (EAAI). Higher EAAI indicates the presence of high concentration of essential amino acid. As shown in Table 5, higher EAAI of CP protein concentrate was obtained compared to soy protein whereas casein EAAI was higher. EAAI indicates that $\mathrm{CP}$ protein concentrate have higher nutritional values compared to soy protein (Bertol et al. 2001; Han et al. 2015; Yi et al. 2013).

\section{Thermal properties}

DSC was used for study the thermal denaturation of protein concentrate (see Fig. 8). The thermal stability of the proteins functionally indicates their resistance to aggregation in response to heating Thermal denaturation of protein is affected by various such as extraction method, pre-treatments, heating and solvents. Literature reports illustrated thermal denaturation temperatures in the range of $75-95{ }^{\circ} \mathrm{C}$ for various protein concentrates (Ghribi et al. 2015; Ibanoglu 2005). In the present study, we found thermal denaturation temperature $\left(T_{\mathrm{d}}\right)$ of $60.10{ }^{\circ} \mathrm{C}$ which is significantly lower compared

Table 4 Composition of amino acids in protein concentrate

\begin{tabular}{ll}
\hline Amino acids & $\begin{array}{l}\text { Protein concentrate } \\
\text { (g/100 g of protein) }\end{array}$ \\
\hline Aspartic acid & $8.12 \pm 0.16$ \\
Glutamic acid & $7.87 \pm 0.23$ \\
Serine & $2.79 \pm 0.03$ \\
Histidine & $1.64 \pm 0.01$ \\
Glycine & $9.73 \pm 0.42$ \\
Threonine & $3.45 \pm 0.04$ \\
Arginine & $5.91 \pm 0.07$ \\
Alanine & $5.08 \pm 0.19$ \\
Tyrosine & $1.22 \pm 0.01$ \\
Phenylalanine & $3.83 \pm 0.11$ \\
Valine & $5.17 \pm 0.05$ \\
Methionine & $3.30 \pm 0.02$ \\
Cysteine & $2.82 \pm 0.06$ \\
Isoleucine & $6.20 \pm 0.14$ \\
Leucine & $3.44 \pm 0.06$ \\
Lysine & $8.14 \pm 0.37$ \\
\hline
\end{tabular}

All the data are expressed as mean \pm SD of two determinations to another protein concentrate. This lower denaturation temperature could be due to various processes involved such as initial drying of biomass, alcohol denaturation during TPP and drying after the partitioning of protein concentrate.

\section{Conclusions}

Microalgae have attracted the attention of the food industry mainly because of the need for valuable, sustainable, unconventional, non-climate-dependent protein source for food and feed. Chlorella species have a great potential to be used as an alternative valuable protein source for humans, especially CP. TPP is an interesting method because of its ability to separate proteins from lipids simultaneously and because it is scalable and an economical process to obtain high protein yields. In this study, it was shown that process parameters such as solvent, ammonium sulphate, solid load, $\mathrm{pH}$, incubation time and slurry to butanol ratio were important in TPP for protein concentration. Enzymatically treated cell lysate of $\mathrm{CP}$ increased protein concentration of protein concentrate. Using optimized TPP parameters and enzymatic treatment, the protein concentration was $78.1 \% \mathrm{w} / \mathrm{w}$. Characterization of this protein concentrate revealed that it was a high-quality protein for human consumption because of its high essential amino acid content. TPP concentrated protein was less intense in colour and also foaming stability was excellent. Thus, TPP concentrated proteins could be easily used in techno-functional applications in pharmaceutical, food and chemical industries.

Table 5 Comparative study of amino acid pattern in CP protein concentrate, soya protein and Casein protein with FAO/WHO/UNU standard and calculation of EAAI

\begin{tabular}{|c|c|c|c|c|}
\hline $\begin{array}{l}\text { Essential } \\
\text { amino } \\
\text { acids (EAA) }\end{array}$ & $\begin{array}{l}\text { CP protein } \\
\text { concentrate } \\
\text { (mg/g } \\
\text { protein) }\end{array}$ & $\begin{array}{l}\text { Soya } \\
\text { protein } \\
\text { (mg/g } \\
\text { protein) } \\
\text { (Bertol } \\
\text { et al. 2001) }\end{array}$ & $\begin{array}{l}\begin{array}{l}\text { Casein } \\
\text { (mg/g }\end{array} \\
\text { protein) } \\
\text { (Han et al. } \\
2015 \text { ) }\end{array}$ & $\begin{array}{l}\mathrm{FAO} / \mathrm{WHO} / \\
\text { UNU } \\
\text { standard } \\
(2007) \\
\text { ( } \mathrm{mg} / \mathrm{g} \text { pro- } \\
\text { tein) }\end{array}$ \\
\hline Histidine & 16 & 12 & 30 & 15 \\
\hline Isoleucine & 62 & 21 & 49 & 30 \\
\hline Leucine & 34 & 35 & 97 & 59 \\
\hline Lysine & 81 & 34 & 82 & 45 \\
\hline $\begin{array}{l}\text { Methionine/ } \\
\text { cysteine }\end{array}$ & 61 & 7 & 29 & 22 \\
\hline $\begin{array}{l}\text { Phenyla- } \\
\text { lanine/ } \\
\text { tyrosine }\end{array}$ & 50 & 24 & 107 & 38 \\
\hline Threonine & 35 & 19 & 43 & 23 \\
\hline Valine & 52 & 24 & 59 & 39 \\
\hline EAAI & 1.35 & 0.657 & 1.66 & \\
\hline
\end{tabular}

$E A A /$ essential amino acid index 


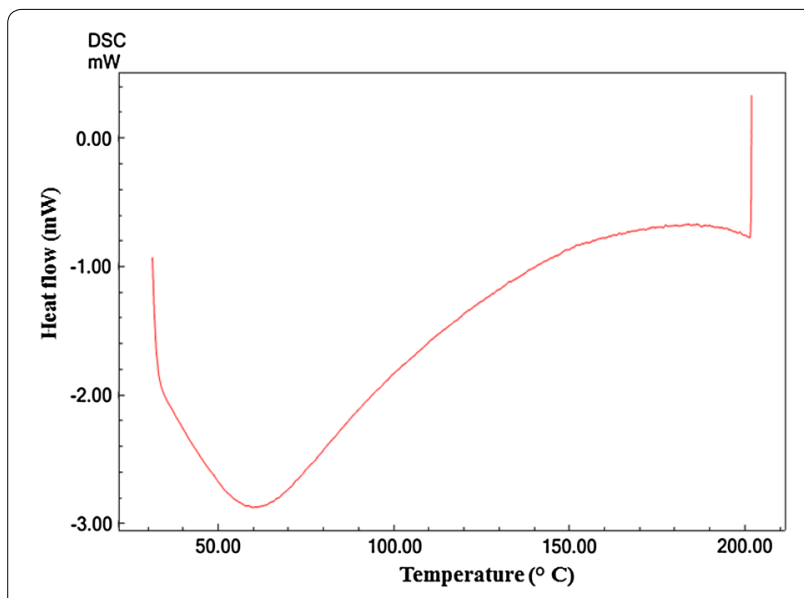

Fig. 8 DSC heating curve of Chlorella pyrenoidosa protein concentrate by TPP

Animal trials and other in vivo studies of the protein concentrate of CP obtained by TPP concentration must be performed to ensure safety and digestibility before proposing its introduction in the food chain of humans and other animals.

\section{Abbreviations}

CP: Chlorella pyrenoidosa; TPP: three-phase partitioning; WHC: water-holding capacity; OHC: oil-holding capacity; FC: foaming capacity; FS: foaming stability; HPLC: high-pressure liquid chromatography; EAAl: essential amino acid index; DSC: differential scanning calorimetry.

\section{Authors' contributions}

AGW have conducted an experiment, analysed results and prepared the manuscript. MKS have analysed samples for protein quantification by Kjeldahl method. JGL have provided technical support and assisted in manuscript drafting. SSA have supervised and guided in experimental work as well as in writing manuscript. All authors read and approved the final manuscript.

\section{Author details}

${ }^{1}$ Food Engineering and Technology Department, Institute of Chemical Technology, Nathalal Parekh Marg Matunga, Mumbai 400 019, Maharashtra, India.

${ }^{2}$ CERELA-CONICET, C.P. 4000 San Miguel de Tucumán, Tucumán, Argentina.

\section{Acknowledgements}

The authors would like to gratefully acknowledge the UGC-SAP, Government of India for their financial support.

\section{Competing interests}

The authors declare that they have no competing interests.

Received: 13 November 2015 Accepted: 14 March 2016

Published online: 26 March 2016

\section{References}

AOAC (Association of Official Analytical Chemists) (2001) Official methods of analysis, 16th edn. Washington

Barbarino E, Lourenço SO (2005) An evaluation of methods for extraction and quantification of protein from marine macro- and microalgae. J Appl Phycol 17:447-460
Becker EW (2007) Micro-algae as a source of protein. Biotechnol Adv 25(2):207-210

Bertol TM, Moraes N, Franke MR (2001) Partial substitution of soybean meal by texturized soybean protein in diets for weaned piglets. J Anim Sci 30:141-149

Bishop WM, Zubeck HM (2012) Evaluation of microalgae for use as nutraceuticals and nutritional supplements. J Nutr Food Sci 2:5

Cano-Medina A, Jimenez-Islas H, Dendooven L, Herrera RP, Gonzalez-Alatorre G, Escamilla-Silva EM (2011) Emulsifying and foaming capacity and emulsion and foam stability of sesame protein concentrates. Food Res Int 44(3):684-692

Chacon-Lee TL, Gonzalez-Marino GE (2010) Microalgae for "healthy" foodspossibilities and challenges. Compr Rev Food Sci F 9:655-675

Cherng JY, Shih MF (2005) Potential hypoglycemic effects of Chlorella in streptozotocin-induced diabetic mice. Life Sci 77:980-990

Dhananjay SK, Mulimani VH (2009) Three-phase partitioning of a-galactosidase from fermented media of Aspergillus oryzae and comparison with conventional purification techniques. J Ind Microbiol Biotechnol 36:123-128

Eskilsson CS, Bjorklund E, Karlsson L, Torstensson A (1999) Microwave-assisted extraction of felodipine tablets. J Chromatogr A 1:59-70

FAO/WHO/UNU (2007) Protein and amino acid requirements in human nutrition. WHO, pp 150 http://whqlibdoc.who.int/trs/WHO_TRS_935_eng.pdf

Gao K (1998) Chinese studies on the edible blue-green alga, Nostoc flagelliforme-A review. J Appl Phycol 10:37-49

Garcia JMR, Fernandez FGA, Sevilla JMF (2012) Development of a process for the production of L-amino-acids concentrates from microalgae by enzymatic hydrolysis. Bioresource Technol 112:164-170

Garg R, Thorat BN (2014) Nattokinase purification by three phase partitioning and impact of $t$-butanol on freeze drying. Sep Purif Technol 131:19-26

GE Healthcare Bio-Sciences (2010) Strategies for protein purification. Amersham Biosciences, Uppsala. http://proteins.gelifesciences.com

Ghribi AM, Gafsi IM, Blecker C, Danthine S, Attia H, Besbes S (2015) Effect of drying methods on physicochemical and functional properties of chickpea protein concentrates. J Food Eng 165:179-188

Halperin SA, Smith B, Nolan C, Shay J, Kralovec J (2003) Safety and immunoenhancing effect of a Chlorella-derived dietary supplement in healthy adults undergoing influenza vaccination: randomized, double-blind, placebo-controlled trial. Can Med Assoc J 169:111-117

Han SW, Chee KM, Cho SJ (2015) Nutritional quality of rice bran protein in comparison to animal and vegetable protein. Food Chem $172: 766-769$

Harde SM, Singhal RS (2012) Extraction of forskolin from Coleus forskohlii roots using three phase partitioning. Sep Purif Technol 96:20-25

Huddleston J, Veide A, Kohlez K, Flanagan J, Enfors SO, Lyddiatt A (1991) The molecular basis of partitioning in ATPS: review. Trends Biotechnol 9:381-388

Huesgen AG (1999) Sensitive and reliable amino acid analysis in protein hydrolysates using the HP 1100 Series HPLC, Hewlett-Packard, Technical Note

Ibanoglu E (2005) Effect of hydrocolloids on the thermal denaturation of proteins. Food Chem 90:621-626

Jones OG (2016) Recent advances in the functionality of non-animal-sourced proteins contributing to their use in meat analogs. Curr Opin Food Sci 7:7-13

Kaur M, Singh N (2007) Characterization of protein isolates from different Indian chickpea (Cicer arietinum L.) cultivars. Food Chem 102(1):366-374

Ketnawa S, Benjakul S, Martínez-Alvarez O, Rawdkuen S (2014) Three-phase partitioning and proteins hydrolysis patterns of alkaline proteases derived from fish viscera. Sep Purif Technol 132:174-181

Lee SK, Fox HM, Kies C, Dam R (1967) The supplementary value of algae protein in human diets. J Nutr 92:281-285

Lisboa CR, Pereira AM, Ferreira SP, Costa JA (2014) Utilisation of Spirulina sp. and Chlorella pyrenoidosa biomass for the production of enzymatic protein hydrolysates. Int J Eng Res Appl 4(5):29-38

Lopez CVG, Garcia MCC, Fernandez FGA, Bustos CS, Chisti Y, Sevilla JMF (2010) Protein measurements of micro-algal and cyanobacterial biomass. Bioresoure Technol 101:7587-7591

Lourenco SO, Barbarino E, Lavin PL, Lanfer Marquez UM, Aidar E (2004) Distribution of intracellular nitrogen in marine microalgae: calculation of new nitrogen-to-protein conversion factors. Eur J Phycol 39(1):17-32 
Merchant RE, Andre CA (2001) A review of recent clinical trials of the nutritional supplement Chlorella pyrenoidosa in the treatment of fibromyalgia, hypertension, and ulcerative colitis. Altern Ther Health Med 7:79-91

Merchant RE, Andre CA, Sica DA (2002) Nutritional supplementation with Chlorella pyrenoidosa for mild to moderate hypertension. J Med Food 5:141-152

Mizoguchi T, Takehara I, Masuzawa T, Saito T, Naoki Y (2008) Nutrigenomic studies of effects of Chlorella on subjects with high-risk factors for lifestyle-related disease. J Med Food 3:395-404

Narayan AV, Madhusudhan MC, Raghavarao KS (2008) Extraction and purification of ipomoea peroxidase employing three phase partitioning. App Biochem Biotechnol 151:263-272

Ozer B, Akardere E, Çelem EB, Onal S (2010) Three-phase partitioning as a rapid and efficient method for purification of invertase from tomato. Biochem Eng J 50:110-115

Persson JA, Wennerholm M, O'Halloran S (2008) Handbook for kjeldahl digestion, FOSS, DK-3400 Hilleroed, Denmark

Phongthai S, Rawdkuen S (2015) Preparation of rice bran protein isolates using three-phase partitioning and its properties. Food Appl Biosci J 3(2):137-149

Rawdkuen S, Vanabun A, Benjakul S (2012) Recovery of proteases from the viscera of farmed giant catfish (Pangasianodon gigas) by three-phase partitioning. Process Biochem 47:2566-2569

Richmond A (1990) Handbook of micro-algal mass culture. CRC Press, Boca Raton

Roe S (2000) Protein purification techniques: a practical approach, 2nd edn. Oxford University Press, Oxford

Safi C, Liu DZ, Yap BHJ, Martin GJO, Vaca-Garcia C, Pontalier PY (2014a) A two-stage ultrafiltration process for separating multiple components of Tetraselmis suecica after cell disruption. J Appl Phycol 26(6):2379-2387

Safi C, Ursu AV, Laroche C, Zebib B, Merah O, Pontalier PY, Vaca-Garcia C (2014b) Aqueous extraction of proteins from microalgae: effect of different cell disruption methods. Algal Res 3:61-65

Şen A, Eryılmaz M, Bayraktar H, Onal S (2011) Purification of a-galactosidase from pepino (Solanum muricatum) by three-phase partitioning. Sep Purif Technol 83:130-136
Smith DM, Nielsen SS (2010) Protein separation and characterization procedures. In: Heldman DR (ed) Food analysis. Springer, Berlin, pp 261-281

Sonawane SK, Bagul MB, LeBlanc JG, Arya SS (2015) Nutritional, functional, thermal and structural characteristics of Citrullus lanatus and Limonia acidissima seed flours. J Food Meas Ch. doi:10.1007/s11694-015-9278-8

Takeshita T, Ota S, Yamazaki T, Hirata A, Zachleder V, Kawano S (2014) Starch and lipid accumulation in eight strains of six Chlorella species under comparatively high light intensity and aeration culture conditions. Bioresoure Technol 158:127-134

Tana ZJ, Wanga CY, Yi YJ, Wanga HY, Zhoua WL, Tana SY, Li FF (2015) Three phase partitioning for simultaneous purification of aloe polysaccharide and protein using a single-step extraction. Process Biochem 50:482-486

Thayumanavan B, Sadasivam S (1984) Physicochemical basis for the preferential uses of certain rice varieties. Plant Food Hum Nutr 34:253-259

Ursu AV, Marcati A, Sayd T, Sante-Lhoutellier V, Djelveh G, Michaud P (2014) Extraction, fractionation and functional properties of proteins from the microalgae Chlorella vulgaris. Bioresource Technol 157:134-139

Ustunol Z (2015) Applied food protein chemistry. John Wiley \& Sons Ltd, Chichester

Vetal MD, Rathod VK (2014) Three phase partitioning a novel technique for purification of peroxidase from orange peels (Citrus sinenses). Food Bioprod Process 487:6

Viegas CV, Hachemi I, Maki-Arvela P, Smeds A, Aho A, Murzin DY (2015) Algal products beyond lipids: comprehensive characterization of different products in direct saponification of green alga Chlorella sp. Algal Res 11:156-164

Vinoth Kumar V, Premkumar MP, Sathyaselvabala VK, Dineshkirupha S, Nandagopal J, Sivanesan S (2011) Aspergillus nigerexo-inulinase purification by three phase partitioning. Eng Life Sci 11:607-614

Walsh G (2007) Pharmaceutical biotechnology, Concept and applications. Wiley, Chichester

Wang X, Zhang X (2012) Optimal extraction and hydrolysis of Chlorella pyrenoidosa proteins. Bioresource Technol 126:307-313

Yi L, Lakemond CMM, Sagis LMC, Eisner-Schadler V, van Huis A, van Boekel MAJS (2013) Extraction and characterisation of protein fractions from five insect species. Food Chem 141(4):3341-3348

\section{Submit your manuscript to a SpringerOpen ${ }^{\circ}$ journal and benefit from:}

- Convenient online submission

- Rigorous peer review

- Immediate publication on acceptance

- Open access: articles freely available online

- High visibility within the field

- Retaining the copyright to your article

Submit your next manuscript at $>$ springeropen.com 